\section{Diversity and Altitudinal Distribution of Squamata in Two Distinct Ecological Zones of Dir, A Himalayan Sub-Zone of Northern Pakistan}

\author{
Qaisar Jamal', Muhammad Idrees', Saif Ullah², Muhammad Adnan', \\ Farrah Zaidi', Qaiser Zaman ${ }^{1,3}$ and Syed Basit Rasheed ${ }^{1, *}$ \\ ${ }^{1}$ Department of Zoology, University of Peshawar, Peshawar, Khyber Pakhtunkhwa \\ ${ }^{2}$ Department of Wildlife Management, PMAS-Arid Agriculture University, \\ Rawalpindi \\ ${ }^{3}$ Deparment of Zoology, Govt. Post Graduate College, Dargai, Malakand, Khyber \\ Pakhtunkhwa
}

\section{A B S T R A C T}

Herpetological fauna of Dir Lower and Dir Upper districts (Northern mountainous region) of Khyber Pakhtunkhwa Pakistan contains 11 species of lizards (Calotes versicolor farooqi, Laudakia agrorensis, Eublepharis macularius, Cyrtopodion scabrum, Hemidactylus brookii, Hemidactylus flaviviridis, Ophisops jerdonii, Asymblepharus himalayanus, Eurylepis taeniolatus, Eutropis dissimilis and Varanus bengalensis) and 16 species of snakes (Eryx johnii, Amphiesma stolatum, Boiga trigonata, Lycodon striatus, Oligodon arnensis, Oligodon taeniolatus, Platyceps rhodorachis, Platyceps ventromaculatus, Ptyas mucosus, Spalerosophis atriceps, Xenochrophis piscator, Gloydius himalayanus, Bungarus caeruleus, Naja oxiana, Typhlops porrectus, Echis carinatus). Altitudinal distribution of reptiles shows that maximum diversity (26 species) has been observed at an altitude range of 550-1000 meters which decreased gradually reaching to occurrence of only four species at 2500-2900 meters above sea level. District Dir lower, primarily sub-tropical, was found more diverse regarding squamate species than the mountainous, temperate Upper Dir.

Article Information
Received 24 November 2017
Revised 11 February 2018
Accepted 05 March 2018
Available online 07 August 2018
Authors' Contribution
QJ and SBR conceived and designed
the study and wrote the article. QJ
and MI collected the specimens and
identified them. SBR and SU made the
altitude maps. MA, FZ and QZ helped
in acquisition of data and edited the
manuscript
Key words
Squamata, Altitude maps, Taxonomy,
Dir.

\section{INTRODUCTION}

D ir, a region in Khyber Pakhtunkhwa lies in the foothills of Himalayas, to the southeast of Hindu Kush in the northwestern Pakistan. Although it has an elevation of 1420 meters above sea level but the topography of the area is dominated by high mountains with highest peak in the extreme north reaching up to a height of 6000 meters above sea level (asl) and the height decreases slowly as we move toward south along the river Panjkora. Karakorum, Hindu Kush and Himalaya form a boundary between the temperate climatic Palearctic zone and tropical and subtropical oriental region (Rafi et al., 2010) so Dir lies in the temperate zone where winters are cold with temperature reaching below freezing point, while summers are hot and humid due to heavy monsoon rains and the temperature may reach up to $32^{\circ} \mathrm{C}$ (Nasrullah et al., 2012). The winter season is from mid-November to March and snowfall continues in the upper parts from December to March during which

\footnotetext{
* Corresponding author: basitrasheed@uop.edu.pk 0030-9923/2018/0005-1835 \$ 9.00/0

Copyright 2018 Zoological Society of Pakistan
}

the peaks remain under snow cover (Khan et al., 2010). Dir shares its boundary with district Chitral in North West, Malakand to the south, Swat in the east and Afghanistan and Bajaur Agency in the west (Hazrat et al., 2007).

Though herpetological fauna of Pakistan has received less attention from investigators and many areas of the country still required an in-depth exploration but work conducted by Boulenger (1890), Minton (1966), Mertens (1969), Khan (2004, 2006), Baig (1998, 2001), Masroor (2011) and Ali et al. (2016) have contributed to the so far neglected field of animal diversity in Pakistan. Currently reptilian fauna of Pakistan comprises of 195 species placed in 23 families of which 13 species are endemic to the country (Khan, 2004). In northern Pakistan, the herpetofauna of Pothohar Plateau, Azad Kashmir and Margalla Hills National Park has been studied extensively. The Province of Khyber Pakhtunkhwa is among the least explored sites of Pakistan in this regard. Despite of the little attention paid to the herpetofauna of this province, its northern areas serves as spots of endemism for the country (Khan, 1997; Ficetoloa et al., 2010). Gymnodactylus walli (Ingoldby, 1922), Allopa hazarnensis (Dubois and Khan, 1979), Cyrtodctylus mintoni (Golubev and Szczerbak, 
1981), Cyrtodactylus battalensis (Khan, 1993) and Cyrtodactylus dattanensis (Khan, 1980) were some new species added to the herpetofaunal list of Pakistan from the Province of Khyber Pakhtunkhwa. All these species reports seem to be a matter of chance sighted by these experts in different tourism spots of the province because no record of the common species is found so far.

The present study was designed to explore the reptile diversity of the area and occurrence of the species in relation to elevation of the area.

\section{MATERIALS AND METHODS}

Regular field surveys (from March to September each year) were conducted in various selected localities of District Dir Lower and Dir Upper for three consecutive years i.e. from 2013 to 2016 . The selected study zones where regular field trips for collection of data and specimens were arranged included Badwan, Shah Alam Baba, Asbanr, Laram Ghar, Timergara and Qambo in Dir lower while Qarodara, Wari, Dir and Dog Dara in Dir upper (Supplementary Fig. S1). Each of these ten selected study zones contained human settlements, agricultural fields, nearby hills and water bodies. All suitable microhabitats (stones, crevices, leaf litter, debris, and rotten logs) were actively searched to find lizards and snakes at dawn, dusk and night time.

A pair of long forceps was used to extract small lizards from crevices while a long strong stick with a forked end was used to pin larger lizards and deal with snakes. Diurnal species were photographed on the spot while nocturnal species were collected and photographed on the subsequent day. The collected specimens were first injected with $37 \%$ formalin in the abdomen and other thick fleshy sites and then fixed in $10 \%$ formalin using air tight bottles to ensure proper preservation and transported the preserved specimens at the end of each season to Natural History Museum of the Department of Zoology University of Peshawar, Pakistan for identification using keys of Minton (1966) and Khan (2004, 2006).

Geographical coordinates for each collection site were acquired at the time of collection using GPS (Garmin eTrex H, USA). An altitude map was constructed from ASTR DEM (30m resolution) image by using ArcGIS v 10.4 and each species was mapped in relation to elevation at its collection site using ArcGIS.

\section{RESULTS AND DISCUSSION}

A total of 391 specimens, belonging to eleven species of lizards and 16 species of snakes were collected from Dir Himalyan Sub-region in Khyber Pakhtunkhwa: Northern
Pakistan (Table I). Dir Lower being warmer and holding more diverse tropical habitats as compared to Dir Upper, a primarily temperate region, was found to be richer regarding squamate fauna. A total of 10 species of Lizards and 15 species of snakes were collected from Dir Lower with three species of lizards and 12 species of snakes exclusively reported from Dir lower while eight species of lizards and 4 species of snakes were reported from Dir Upper with a single species of each group exclusively present in Dir Upper only.

Table I.- Species of reptiles collected from Dir area of Northern Pakistan.

\begin{tabular}{|c|c|c|}
\hline Families & Species & Common Name \\
\hline \multicolumn{3}{|l|}{ Lizards } \\
\hline \multirow[t]{2}{*}{ Agamidae } & $\begin{array}{l}\text { Calotes versicolor } \\
\text { farooqi }\end{array}$ & Common garden lizard \\
\hline & Laudakia agrorensis & Agror agama \\
\hline \multirow[t]{3}{*}{ Gekkonidae } & Cyrtopodion scabrum & Rough bent toed gecko \\
\hline & $\begin{array}{l}\text { Hemidactylus } \\
\text { flaviviridis }\end{array}$ & $\begin{array}{l}\text { Yellow-bellied house } \\
\text { gecko }\end{array}$ \\
\hline & H. brookii & Spotted house gecko \\
\hline \multirow[t]{3}{*}{ Scincidae } & Eurylepis taeniolatus & Ribbon sided skink \\
\hline & Eutropis dissimilus & Alpine Punjab skink \\
\hline & $\begin{array}{l}\text { Asymblepharus } \\
\text { himalayanus }\end{array}$ & Himalaya ground skink \\
\hline Eublepharidae & $\begin{array}{l}\text { Eublepharis } \\
\text { macularius }\end{array}$ & Leopard gecko \\
\hline Lacertidae & Ophisops jerdonii & Punjab snake eyed lizard \\
\hline Varanidae & Varanus bengalensis & The Bengal monitor \\
\hline \multicolumn{3}{|l|}{ Snakes } \\
\hline \multirow[t]{10}{*}{ Colubridae } & Amphiesma stolatum & Buff striped keelback \\
\hline & Xenochrophis piscator & Asiatic water snake \\
\hline & Boiga trigonata & Indian gamma snake \\
\hline & Platyceps rhodorachis & Braid snake \\
\hline & P. ventromaculatus & Glossy bellied racer \\
\hline & Oligodon arnensis & Common kukri snake \\
\hline & O. taeniolatus & Variegated kukri \\
\hline & Lycodon striatus & Northern wolf snake \\
\hline & Ptyas mucosus & Oriental rat snake \\
\hline & Spalerosophis atriceps & Diadem or royal snake \\
\hline Viperidae & Echis carinatus & Saw scaled viper \\
\hline \multirow[t]{2}{*}{ Elapidae } & Naja oxiana & Caspian cobra \\
\hline & Bungarus caeruleus & Common krait \\
\hline Boidae & Eryx johnii & Indian sand boa \\
\hline Crotalidae & Gloydius himalayanus & Himalayan pit viper \\
\hline Typhlopidae & Typhlops porrectus & Slender worm snake \\
\hline
\end{tabular}


Among lizards reported in this study distribution wise Hemidactylus brookii has worldwide occurrence while Hemidactylus flaviviridis and Cryptodian scabrum distribution ranges from Asia to north eastern Africa. Eurylepis taeniolatus occurs from western India to Afghanistan and Middle East while Eutropis dissimilis distribution is restricted to South Asia and Afghanistan (Khan, 2006). C. versicolor and Veranus bengalensis is widely distributed in Asia and occurs in Iran, Afghanistan, Pakistan, India, Nepal, Bhutan, Myanmar, Srilanka, Bangladesh, Thailand, Malaysia and Vietnam (Khan, 2006). Assymlepharus himalayanus occurs in Nepal and Turkmenistan and in northern parts of India and Pakistan, Eublepharis macularius has been reported from Iran, Afghanistan, Pakistan and India while Laudakia agrorensis and Ophisops jerdonii are restricted to India, Pakistan and Afghanistan only (Masroor, 2012).

Among snakes Amphiesma stolatum is distributed throughout East Asia and South Asia, while Xenochrophis piscator occurs from East Asia to Afghanistan. Boiga trigonata has been reported from Inida, Bangladesh, Nepal, Bhutan, Srilanka, Pakistan, Afghanistan, Iran, Turkmenistan, Uzbekistan and Kyrgyzstan. Platyceps rhodorachis distribution ranges from Pakistan, Iran, Afghanistan to central Asia and Northern Africa (Khan, 2006) Tyas mucosus occurs from East Asia to Afghanistan, Iran and Turkemanistan. Spalerosophis atriceps, Gloydius himalayanus and Oligodon arnensis is restricted to India, Nepal and Pakistan while Oligodon taeniolatus occurs in India, Pakistan, Afghanistan, Iran and Turkmenistan (Saikia et al., 2007) Naja oxiana has been reported from north western India, Pakistan, Afghanistan, Iran, Uzbakistan and Turkemanistan. Bungarus caeruleus distribution range from Bangladesh to Afghanistan and Echis carinatus has wide range of distribution in South Asia, central Asia and Middle East. Eryx johnii occurs in Nepal, India, Pakistan, Afghanistan and Iran while Typhlops porrectus is distributed in Pakistan, Nepal, India, Myanmar and Thailand (Masroor, 2012).

Altitude map shows that elevation of Dir varies from 550-5500 meter asl. Reptiles in Dir were found to be distributed between 550 and 2900 meters asl as no reptile species was observed above 2900 meters asl. Mapping of the collected species on an altitude map revealed maximum diversity of reptiles in the study area at an altitude range of 550-1000 meters asl. Diversity of species decreased from 26 species at 550-1000 meters to only four species at 2500-2900 meters asl.

A decline in species diversity was also observed when considering lizards and snakes separately. Among 11 species of lizards reported in the current study nine were observed at less than 1000 meters asl. Eutropis dissimilis was the only species among lizards which was not collected from areas having altitude above 1000 meters asl, while Laudakia agrorensis, and Varanus bengalensis were observed at low as well as altitudes above 2500 meters asl. Asymblepharus himalayanus was seen only at high altitudes i.e. above 1750 meters asl and were not observed below this altitude (Supplementary Fig. S2). A very steep decline in species diversity of snakes was observed above 1000 meters and diversity reduced to almost half as we move higher from 1000 meters (Supplementary Fig. S3). Only Gloydius himalayanus was collected from high altitudes of above 1750 meters till 2900 meters asl while Amphiesma stolatum, Xenochrophis piscator, Oligodon taeniolatus, Spalerosophis atriceps, Echis carinatus and Eryx johnii were not collected above an altitude of 1000 meters asl.

Altitudinal distribution of species of squamata reported in the current study shows that species like Hemidactylus flaviviridis, Cyrtopodion scabrum, Eutropis dissimilis, Amphiesma stolatum, Xenochrophis piscator, Oligodon arnensis, Oligodon taeniolatus, Spalerosophis atriceps, Naja oxiana, Echis carinatus, Eryx johnii and Gloydius himalayanus were reported from areas of same altitudinal range as were reported previously by other investigators working in this part of the world (Vidal, 1890; Wall, 1911; Whitaker, 1978; Masroor, 2012; Khan, 2015).

In lizards Calotes versicolor is widely distributed in Pakistan, however, two subspecies Calotes versicolor versicolor and Calotes versicolor farooqi has been reported from Pakistan, with later restricted to northern areas i.e. foothills of Himalaya mountains only. Altitudinal distribution of these two subspecies also differ, $C . v$. versicolor occurs below 1400 meters while C. v. farooqi is distributed above 1800 meters asl (Khan, 2015). Present study reports this species from below 1000 meters asl to an altitude of as high as 2300 meters at Laram Ghar with no significant difference in their morphology. Based on altitudinal distribution observed in current study, it is suggested that the status of two-subspecies may be reviewed and confirmed via molecular identification and characterization.

Asymblepharus himalayanus normally are found on forest floors, on mountain sides, in grassy alpine meadows and along the margins of water bodies reported between 2600-4500 m asl (Masroor, 2012) but in our study this lizard has been reported from lower altitudes of $1700 \mathrm{~m}$ at Dir city along with its normal altitudinal range of above $2600 \mathrm{~m}$ at Dog Dara. Common habitat of this lizard is mountain sides and margins of water bodies, the study area mainly consisted of valleys having streams, rivers and grassy meadows, which in turn is the common habitat 
of this lizard. Ophisops jerdonii have been reported from 1400-2000 m asl (Blanford, 1876; Khan, 2015) but this study revealed that the species has a wide altitudinal range of distribution and was observed from $600 \mathrm{~m}$ to as high as $2300 \mathrm{~m}$ asl.

Laudakia agrorensis and Hemidactylus brookii have been reported from up to an elevation of $1400 \mathrm{~m}$ (Khan, 2015) but in the present study Hemidactylus brookii was collected from Laram Ghar at an altitude of $2300 \mathrm{~m}$, while Laudakia agrorensis not only was collected at Laram Ghar but also towards the north in Dog Dara having at an elevation of $2600 \mathrm{~m}$ asl. Eublepharis macularius and Varanus bengalensis has previously been reported from an altitude of $1800 \mathrm{~m}$ asl (Khan, 2015) and Eurylepis taeniolatus from an altitude of $2260 \mathrm{~m}$ (Minton, 1966). Current study reports Eublepharis macularis and Eurylepis taeniolatus from Laram Ghar $(2300 \mathrm{~m})$ while Varanus bengalensis was collected from Laram Ghar as well as Dog Dara (2600 m).

Among snakes reported in this work Platyceps ventromaculatus and Bungarus caeruleus were said to occur at an altitude of $1000 \mathrm{~m}$ asl while Boiga trigonata has been previously reported at an altitude of $1400 \mathrm{~m}$ in Pakistan (Khan, 2015) but Wall $(1908,1928)$ reported the same species from $1800 \mathrm{~m}$ in India. Platyceps rhodorachis has been reported from an altitude of $2440 \mathrm{~m}$ in Afghanistan (Anderson and Leviton, 1969) but from Pakistan previous record of its occurrence is at an altitude of $1900 \mathrm{~m}$ (Khan, 2015), Lycodon striatus was previously recorded at altitudes of below $1800 \mathrm{~m}$ and Ptyas mucosus from altitudes below $2000 \mathrm{~m}$ in Pakistan (Khan, 2015), though Whitaker (1978) reported this species at an elevation of 4000 from India. In Pakistan, Typhlops porrectus is known by its junior synonym Typhlops ductuliformes and no evidence has been established so far regarding the status of the species (Masroor, 2011) but previously it has been reported from planes of Pakistan having an altitude of 1200 $\mathrm{m}$ (Khan, 2015). All these species mentioned above were collected from Laram Ghar, which is an elevated peak in Dir Lower having an altitude of approximately 2300 $\mathrm{m}$ and is surrounded by warmer areas thus extends their altitudinal range further for the collected species except for Ptyas mucosus which has already been reported from $4000 \mathrm{~m}$.

All the species collected during this study have not been reported previously from Dir valley. District Dir lower, primarily sub-tropical, was found more diverse regarding squamate species than district Upper Dir which is dominantly temperate with prolonged winters and lower temperature. Laram Ghar is an elevated peak of Dir Lower, most of the species reported here with extended altitudinal range were collected from this elevated peak of
Dir Lower. The possible reason may be that Laram Ghar is topographically surrounded by low altitude and warmer climatic areas. The Dir region with its characteristic rough and mountainous terrain and blend of tropical and temperate areas possesses unique faunal characteristics still awaiting exploration.

\section{ACKNOWLEDGEMENTS}

The authors are thankful to Rafaqat Masroor of Pakistan Museum of Natural History Islamabad, for providing necessary help in finding the relevant literature.

\section{Supplementary material}

There is supplementary material associated with this article. Access the material online at: http://dx.doi. org/10.17582/journal.pjz/2018.50.5.1835.1839

\section{Statement of conflict of interest}

Authors have declared no conflict of interest.

\section{REFERENCES}

Ali, W., Javid, A., Hussain, S.M., Azmat, H. and Jabeen, G., 2016. The amphibians and reptiles collected from different habitat types in District Kasur, Punjab, Pakistan. Pakistan J. Zool., 48: 1201-1204.

Anderson, S.C. and Leviton, A.E., 1969. Amphibians and reptiles collected by the street expedition to Afghanistan. Proc. Calif. Acad. Sci., 37: 25-56.

Baig, K.G., 1998. The amphibians fauna of Azad Jammu and Kashmir with new record of Paa liebigii. Proc. Pak. Acad. Sci., 35: 117-121.

Baig, K.G., 2001. Annotated checklist of amphibians and reptiles of the northern mountain region and Potwar plateau of Pakistan. Proc. Pak. Acad. Sci., 38: $121-130$.

Blanford, W.T., 1876. On some new lizards from Sindh with description of new species of Ptyodactylus, Stenodactylus and Trapelus. J. Asiatic Soc. Bengal, 45: 18-26.

Boulenger, G.A., 1890. The fauna of British India including Ceylon and Burma: Reptilia and Batrichia. Taylor and Francis, London.

Chettri, B., Bhupathy, S. and Acharya, B.J., 2010. Distribution pattern of reptiles along an eastern Himalayan elevation gradient, India. Acta Oecol., 36: 16-22. https://doi.org/10.1016/j. actao.2009.09.004

Dubois, A. and Khan, M.S.A., 1979. New species of frog (Genus Rana, Subgenus Paa) from Northern Pakistan (Amphibia, Anura). J. Herpetol., 13: 403- 
410. https://doi.org/10.2307/1563474

Ficetoloa, G.F., Crottini, A., Casiraghi, M. and PadoaShioppa, E., 2010. New data on amphibian and reptiles of Pakistan: Distribution, genetic variability and conservation issues. North-Western J. Zool., 6: $1-12$.

Gaston, K.J., Williams, P.H., Eggleton, P. and Humphries, C.J., 1995. Large-scale patterns of biodiversity-spatial variation in family richness. Proc. R. Soc. Lond. Ser. B: Biol. Sci., 260: 149-154.

Golubev, M.L. and Szczerbak, N.N., 1981. A new species of Gymnodactylus Spix, 1923 (Reptilia, Sauria, Geckkonidae) from Pakistan. Fauna Syst., 1981: 40-45.

Hazrat, A., Shah, J., Ali, M. and Iqbal, I., 2007. Medicinal value of ranunculaceae of Dir valley. Pak. J. Bot., 39: 1037-1044.

Heatwole, H.F. and Taylor, J., 1987. Ecology of reptiles. Surrey Beatty and Sons, Chipping Norton, NSW.

Ingoldby, C.M., 1922. A new stone gecko from Himalayas. J. Bombay Nat. Hist. Soc., 28: 1051.

Khan, M.S., 1980. A new species of gecko from northern Pakistan. Pakistan J. Zool., 12: 11-16.

Khan, M.S., 1993. A new angular-toed gecko from Pakistan, with remarks on the taxonomy and a key to the species belonging to genus Cyrtodactylus (Reptilia: Sauria: Geckkonidae). Pakistan J. Zool., 25: 67-73.

Khan, M.S., 1997. Biodiversity of Pakistan. Pakistan Museum of Natural History Islamabad, Pakistan and Florida Museum of Natural History, Gainesville, Florida, USA.

Khan, M.S., 2004. Annotated checklist of amphibians and reptiles of Pakistan. Asiat. Herpetol. Res., 10: 191-201.

Khan, M.S., 2006. Amphibians and reptiles of Pakistan. Krieger Publishing Company, Malabar, Florida.

Khan, N., Ahmed, M., Wahab, M., Ajaib, M. and Hisain, S.S., 2010. Studies along an altitudinal gradient in Monotheca buxifolia (falc.) A.D, forest, District Lower Dir, Pakistan. Pak. J. Bot., 42: 3029-3038.
Khan, M.S., 2015. Affinities and altitudinal distribution of amphibians and reptiles in Pakistan. Herp Laboratory 306 N. Morton Ave Morton, Pa19070.

Masroor, R., 2011. An annotated checklist of amphibians and reptiles from Margalla Hills National Park, Pakistan. Pakistan J. Zool., 43: 1041-1048.

Masroor, R., 2012. A contribution to the herpetology of Northern Pakistan. Society for the Study of Amphibians and Reptiles, USA, pp. 217.

Mertens, R., 1969. Die amphibiens und reptiliens West Pakistan. Stutt. Beit. Naturk., 197: 1-96.

Minton, S.A., 1966. A contribution to the herpetology of West-Pakistan. Bull. Am. Mus. Nat. Hist., 134: 31-184.

Nasrullah, Bano, A., Nisar, M., Suliman, M. and Ali, M., 2012. Ethnobotanical wealth of Jandool Valley, Dir Lower, Khyber Pakhtunkhwa, Pakistan. Int. J. Phytomed., 4: 351-354.

Rafi, M.A., Jurgen, W., Matin, M.A., Zia, A., Sultan, A. and Naz, F., 2010. Faunistics of tiger beetles (Coleoptera: Cicindelidae) from Pakistan. J. Insect Sci., 10: 116. https://doi.org/10.1673/031.010.11601

Saikia, U., Sharma, D.K. and Sharma R.M., 2007. Checklist of the reptilian fauna of Himachal Pardesh, India. Reptile Rap., 8: 6-9.

Vidal, G.W., 1890. A list of venomous snakes of North Kanara, with remarks on the existing records of distribution of snake Echis carinatus near Bombay Presidency. J. Bombay Nat. Hist. Soc., 5: 64-71.

Wall, F., 1908. A popular treatise on the common Indian snakes, Part VIII. Bungarus. J. Bombay Nat. Hist. Soc., 18: 711-735.

Wall, F., 1911. Reptiles collected in Chitral. J. Bombay Nat. Hist. Soc., 21: 12-145.

Wall, F., 1928. The poisonous terrestrial snakes of our British Indian Dominions (including Ceylon) and how to recognize them, with symptoms of snake poisoning and treatment, $4^{\text {th }}$ Edition. Bombay Nat Hist. Soc., Bombay.

Whitaker, R., 1978. Common Indian snakes: A field guide. Macmillan, New Delhi. 